\title{
Kebijakan Nonpenal oleh Badan Narkotika Nasional Provinsi Jambi terhadap Penyalahguna Narkotika
}

\author{
Reza Iswanto ${ }^{1}$ \\ Fakultas Hukum Universitas Batanghari \\ Email : rezaiswanto17@gmail.com
}

\begin{abstract}
Abstrak
Penyalahgunaan narkotika sekarang ini semakin meningkat dan telah banyak korban yang berjatuhan akibat penyalahgunakan narkotika. Untuk itu, peran Badan Narkotika Nasional Provinsi Jambisangat dibutuhkan dalam mengatasi tingkat penyalahgunaan narkotika. Dalam melakukan kebijakan nonpenal, Badan Narkotika Nasional Provinsi Jambi hanyamelakukan sosialisasi disekolah-sekolah dan rehabilitasi hanya menampung untuk 10 penyalahguna narkotika. Dengan demikian, solusi dalam menggunakan kebijakan nonpenal tersebut adalah Badan Narkotika Nasional Provinsi Jambi harus mengingkatkan sosialisasi, membuat komunitas-komunitas dari para mantan penyalahguna narkotika yang sudah sembuh untuk dijadikan pembimbing terhadap penyalahguna narkotika yang baru masuk rehabilitasi, harus bekerja sama dengan kepolisian untuk melakukan razia, menggunakan peran media massa dalam memberikan berita tentang bahaya menyalahgunaan narkotika dan Badan Narkotika Nasional Provinsi Jambi harus menyediakan panti rehabilitasi penyalahguna narkotika.Untuk mendapatkan solusi tersebut, makadigunakan pendekatan sosiologi hukum dengan mengutamakan data primer yang dilakukan dengan wawancara dan berlokasi di Badan Narkotika Nasional Provinsi Jambi.
\end{abstract}

Kata Kunci : Kebijakan, Badan Narkotika Nasional Provinsi

\begin{abstract}
Narcotics abuse is increasing now and many victims have fallen victim to drug abuse. Therefore, the role of the National Narcotics Board of Jambi Province is needed in overcoming the level of narcotics abuse. In conducting nonpenal policy, the National Narcotics Board of Jambi Province only conducts socialization in schools and rehabilitation only accommodates 10 drug abusers. Thus, the solution in using the nonpenal policy is the National Narcotics Board of Jambi Province should increase the socialization, make the communities of ex-narcotics abusers who have recovered to be guides against new drug abuse entrants into rehabilitation, should work together with the police to conduct raids, using the role of mass media in providing news about the dangers of drug abuse and the National Narcotics Board of Jambi Province should provide rehabilitation center for narcotics abusers. To get the solution, then used the approach of sociology of law by giving priority to primary data conducted by interview and located in National Narcotics Agency of Jambi Province.
\end{abstract}

Keywords: Policy, National Provincial Narcotics Board

\section{PENDAHULUAN}

Sekarang ini Provinsi Jambi mendapat ranking 4 se-Indonesia dengan jumlah penyalahguna narkoba sebanyak 53.177. Hal ini tentu menjadi perhatian yang serius karena pada tahun 2015 tingkat penyalahgunaan narkotika menjadi peringkat 24 se-Indonesia. Jumlah tersebut dijelaskan oleh Badan Narkotika Nasional Provinsi Jambi dengan pengelompokkan mulai dari coba pakai, teratur pakai, pecandu suntik sampai pecandu non suntik. Dengan demikian telah terbukti bahwa Provinsi Jambi dalam keadaan darurat narkoba. Oleh karena itu, mengingat akan bahaya narkotika yang semakin terus bertambah, maka perlu diadakan suatu kebijakan yang dapat mencegah agar tingkat penyalahgunaan narkotika di Provinsi Jambi tidak semakin meningkat.

Salah satu kebijakan yang biasanya dilakukan oleh Badan Narkotika Nasional Provinsi Jambi adalah melakukan pengawasan terhadap peredaran dan penyalahguna narkotika di Provinsi Jambi. Akan tetapi, dalam meminimalisir penyalahguna narkotika tidak saja hanya melalui pengawasan saja. Tentu harus dilakukan kebijakan-kebijakan lain untuk dapat mengatasi tingkat penyalahgunaan narkotika yang semakin parah di Provinsi Jambi.

Untuk itu, Badan Nasional Provinsi Jambi selain melakukan pengawasan terhadap peredaran dan penyalahguna narkotika di Provinsi Jambi. Badan Nasional Provinsi Jambi juga melakukan berbagai

\footnotetext{
${ }^{1}$ Dosen Fakultas Hukum Universitas Batanghari
} 
kebijakan seperti kebijakan nonpenal terhadap penyalahguna narkotika di Provinsi Jambi. Hal yang demikian juga dijelaskan oleh Abintoro Prakoso bahwa usaha-usaha yang rasional untuk mengendalikan atau menanggulangi kejahatan (politk kriminal), sudah barang tentu tidak hanya menggunakan sarana penal (hukum pidana), namun juga dengan menggunakan sarana-sarana nonpenal. ${ }^{2}$

Jalur nonpenal lebih menitikberatkan pada sifat preventive (pencegahan/ penangkalan/pengendalian) sebelum kejahatan terjadi. ${ }^{3}$ Usaha-usaha nonpenal misalnya penyantunan dan pendidikan sosial dalam rangka mengembangkan tanggung jawab sosial warga masyarakat, penggarapan jiwa masyarakat melalui pendidikan moral dan agama, peningkatan usaha-usaha kesejahteraan anak dan remaja, kegiatan patroli dan pengawasan lainnya secara kontinyu oleh polisi dan aparat keamanan lainnya. ${ }^{4}$

Dengan demikian, tujuan dari kebijakan nonpenal ini adalah mencegah terhadap masyarakat dan generasi muda yang belum pernah menjadi penyalahguna atau pecandu narkotika sehingga mereka tidak menggunakan narkotika dan memulihkan kembali terhadap masyarakat atau generasi muda yang telah terlanjur terjerumus dalam menggunakan narkotika sehingga masyarakat atau generasi muda tersebut dapat terlepas dari kecanduan akan narkotika.

Untuk mencapai tujuan dari kebijakan nonpenal tersebut, pihak Badan Narkotika Nasional Provinsi Jambi melakukan sosialisasi terhadap yg belum menjadi penyalahguna atau pecandu narkotika dan melakukan rehabilitasi terhadap penyalahguna narkotika.

Masalah rehabilitasi terhadap penyalahguna atau pecandu narkotika telah diatur dalam Pasal 54 Undang-Undang Nomor 35 Tahun 2009 Tentang Narkotika yang mewajibkan pecandu narkotika dan korban penyalahgunaan narkotika untuk menjalani rehabilitasi medis dan rehabilitasi sosial. Rehabilitasi medis dilakukan supaya pecandu dan korban penyalahgunaan narkotika secara bertahap dapat terlepas dari kecanduan narkotika, sedangkan rehabilitasi sosial dilakukan terhadap pecandu dan korban penyalahgunaan narkotika agar mereka setelah terlepas dari kecanduan narkotika, mereka dapat melakukan aktivitas yang bermanfaat dalam kehidupan sehari-hari.

Dalam hal ini, Badan Narkotika Nasional Provinsi Jambi telah melakukan berbagai kebijakan nonpenal seperti sosialisasi dan rehabilitasi. Akan tetapi, pada kenyataannya seperti sekarang ini, walaupun Badan Narkotika Nasional Provinsi Jambi telah melakukan sosialisasi masih juga tingkat penyalahgunaan narkotika di Provinsi Jambi meningkat.

Dengan demikian, kebijakan nonpenal yang dilakukan oleh Badan Narkotika Nasional Provinsi Jambi belum mendapatkan hasil yang diinginkan yaitu menurunkan tingkat penyalahgunaan narkotika di Provinsi Jambi.Hal yang demikian harus menjadi perhatian agar dalam menggunakan kebijakan nonpenal harus lebih tepat dan cepat dalam mengatasi tingkat penyalahgunaan narkotika di Provinsi Jambi.

Berdasarkan diuraikan pada latar belakang di atas, maka penulis akan membatasi permasalahan yang akan dibahas dalam penelitian ini yaitu sebagai berikut :

1. Bagaimana kebijakan nonpenal oleh Badan Narkotika Nasional Provinsi Jambi terhadap penyalahguna narkotika?

2. Apa saja kendala-kendala yang dihadapi dalam melakukan kebijakan nonpenal oleh Badan Narkotika Nasional Provinsi Jambi terhadap penyalahguna narkotika?

3. Bagaimana solusi dalam melakukan kebijakan nonpenal oleh Badan Narkotika Nasional Provinsi Jambi terhadap penyalahguna narkotika?

Kemudian tujuan tulisan ini untuk mengetahui kebijakan nonpenal oleh Badan Narkotika Nasional Provinsi Jambi terhadap penyalahguna narkotika, untuk memaparkan kendala-kendala yang dihadapi dalam melakukan kebijakan nonpenal oleh Badan Narkotika Nasional Provinsi Jambi terhadap penyalahguna narkotika dan untuk menjelaskan solusi dalam melakukan kebijakan nonpenal oleh Badan Narkotika Nasional Provinsi Jambi terhadap penyalahguna narkotika.

\footnotetext{
2 Abintoro Prakoso, Kriminologi Hukum Pidana, (Yogyakarta: Laksbang Grafika, 2013), halaman 155.

${ }^{3}$ Barda Nawawi Arief, Bunga Rampai Kebijakan Hukum Pidana, (Jakarta, Kencana, 2014), halaman 46.

4 Ibid.
} 


\section{METODE PENELITIAN}

Agar penelitian ini dapat mencapai kebenaran yang diinginkan secara ilmiah dan objektif, maka diperlukan metode penelitian secara konsisten dan sistematis, yaitu :

\section{Metode pendekatan}

Sebelum membahasa metode pendekatan, penulis terlebih dahulu menjelaskan bahwa tipe penelitian ini adalah yuridis empiris. Menurut Soerjono Soekanto dan Sri Mamuji, Tipe penelitian hukum sosiologis atau empiris adalah penelitian hukum yang dilakukan dengan cara meneliti data primer. ${ }^{5}$ Data Primer merupakan data yang berasal dari masyarakat dan/atau orang yang terlibat secara langsung terhadap masalah yang diteliti. ${ }^{6}$ Dengan demikian, tipe penelitian ini dilakukan dengan cara mempelajari langsung penerapan oleh Badan Narkotika Nasional Provinsi Jambi.

Kemudian pendekatan yang digunakan dalam penelitian ini yaitu pendekatan sosiologi hukum. Pendekatan sosiologi hukum merupakan pendekatan yang menganalisis tentang bagaimana reaksi dan interaksi yang terjadi ketika sistem norma itu bekerja di dalam masyarakat. ${ }^{7}$ Dalam hal ini, melihat reaksi masyarakat ketika adanya penerapan kebijakan nonpenal yang dilakukan oleh Badan Narkotika Nasional Provinsi Jambi.

\section{Rancangan kegiatan}

Dalam penelitian yuridis empiris ini rancangan kegiatannya adalah melihat kebijakan nonpenal apa saja yang dilakukan oleh Badan Narkotika Nasional Provinsi Jambi terhadap masyarakat Jambi terutama kepada penyalahguna narkotika dan terhadap masyarakat yang belum terjerat ke dalam penyalahgunaan narkotika.

\section{Ruang lingkup atau objek}

Objek kajian penelitian hukum empiris menurut Peter Mahmud Marzuki adalah sebagai berikut : ${ }^{8}$

a. Efektivitas aturan hukum.

b. Kepatuhan terhadap aturan hukum.

c. Peranan lembaga atau instansi hukum dalam penegakan hukum.

d. Implementasi aturan hukum.

e. Pengaruh aturan hukum terhadap masalah sosial tertentu atau sebaliknya.

f. pengaruh masalah sosial tertentu terhadap aturan hukum.

Dengan demikian, ruang lingkup atau objek dalam penelitian ini yaitu peran Badan Narkotika Nasional Provinsi Jambi dalam penegakan Undang-Undang Nomor 35 Tahun 2009 Tentang narkotika.

\section{Bahan dan alat utama}

Bahan dalam penelitian ini adalah data primer. Data primer yakni data yang diperoleh sumbernya langsung dari lapangan. ${ }^{9}$ Dengan demikian, sumber data primer adalah hasil wawancara terhadap Badan Narkotika Nasional Provinsi Jambi. Sedangkan alat utama dalam penelitian ini adalah menggunakan handphone untuk merekam wawancara dengan narasumber.

\section{Tempat}

Dalam penelitian empiris mempergunakan tempat/lokasi penelitian. Lokasi penelitian ini merupakan lingkungan tempat dilakukannya penelitian. ${ }^{10}$ Jadi, tempat/lokasi yang digunakan dalam ini yaitu Kantor Badan Narkotika Nasional Provinsi Jambi.

${ }^{5}$ H. Salim HS, Erlies Septiana Nurbani, Penerapan Teori Hukum Pada Penelitian Tesis dan Disertasi, (Jakarta, PT. Raja Grafindo Persada, 2013), halaman 20.

6 Ibid.

${ }^{7}$ I Made Pasek Diantha, Metodologi Penelitian Hukum Normatif Dalam Justifikasi Teori Hakum, (Jakarta, Kencana, 2016), halaman 23.

${ }^{8}$ Ishaq, Metode Penelitian Hukum Dan Penulisan Skripsi, Tesis Serta Disertasi, (Bandung: Alfabeta, 2017), halaman 7071.

\footnotetext{
${ }^{9}$ Ibid.

${ }^{10}$ Ishaq, Op.Cit, halaman 70-71.
} 


\section{Teknik pengumpulan data}

Teknik pengumpulan data primer dalam penelitian hukum empiris meliputi wawancara, observasi dan kuesioner. ${ }^{11}$ Dalam penelitian ini, teknik pengumpulan data dilakukan dengan wawancara kepada Badan Narkotika Nasional Provinsi Jambi.

\section{Definisi operasional variabel penelitian}

Definisi operasional variabel penelitian ini yaitu definisi yang penyusunannya berdasarkan atas kegiatan-kegiatan (operations) yang harus dilakukan agar hal yang didefinisikan itu terjadi. ${ }^{12}$ Dalam penelitian ini, definisi operasional variabel penelitian adalah kebijakan nonpenal dilakukan oleh Badan Narkotika Nasional Provinsi Jambi karena masih banyak penyalahguna narkotika yang menjadi korban di Provinsi Jambi.

\section{Teknik analisis}

Teknik analisis dalam penelitian empiris adalah analisis kualitatif. Analisis kualitatif merupakan analisis data yang tidak menggunakan angka melainkan memberikan gambaran-gambaran atau deskripsi dengan kata-kata atas temuan-temuan dan karenanya ia lebih mengutamakan mutu atau kualitas daripada data dan bukan kuantitas. ${ }^{13}$

Dengan demikian, teknik analisis dalam penelitian ini adalah mendeskripsikan hasil dari lapangan terkait dengan kebijakan nonpenal yang telah dilakukan oleh Badan Narkotika Nasional Provinsi Jambi terkait dengan kebijakan nonpenal.

\section{HASIL DAN PEMBAHASAN}

Kebijakan Nonpenal Oleh Badan Narkotika Nasional Provinsi Jambi Terhadap Penyalahguna Narkotika

Salah satu tugas Badan Narkotika Nasional Provinsi Jambi yaitu mencegah dan memberantas penyalahgunaan dan peredaran gelap narkotika dan prekursor narkotika. Untuk melaksanakan tugas tersebut, Abdul Razakmengatakan bahwa dalam pertemuan Perserikatan Bangsa-Bangsa di Jakarta, Badan Narkotika Nasional di Indonesia lebih menekankan di bidang pencegahan daripada pemberantasan.Hal demikian dilakukan sebab pencegahan dilakukan dengan mudah apabila masyarakat Jambi belum semuanya terjerat ke dalam penyelahgunaan narkotika. Apabila masyarakat Jambi telah menjadi penyalahguna narkotika cukup sulit untuk menyembuhkannya. ${ }^{14}$ Untuk itu, pihak Badan Narkotika Nasional Provinsi Jambi lebih memfokuskan terhadap upaya nonpenal daripada menggunakan upaya penal.

Usaha-usaha yang rasional untuk mengendalikan atau menanggulangi kejahatan (politik kriminal), namun juga dengan menggunakan sarana-sarana nonpenal. Menurut G. P. Hoefnagels upaya penanggulangan kejahatan dapat ditempuh dengan $:^{15}$

a. Penerapan hukum pidana (criminal Law application).

b. Pencegahan tanpa pidana (prevention without punishment) dan

c. Mempengaruhi pandangan masyarakat mengenai kejahatan dan pemidanaan lewat media massa (influencing views of society on crime and punishment/mass media).

Dengan demikian, kebijakan nonpenal tersebut merupakan kebijakan yang dilakukan dengan mencegah agar penyalahguna yang telah menggunakan narkotika tersebut tidak menjalani hukuman, melainkan menjalani rehabilitasi untuk supaya semuh dari ketergantungan narkotika tersebut dan mempengaruhi pandangan masyarakat mengenai akan bahaya menggunakan narkotika bagi kesehatan tubuh.

Secara kasar dapat dibedakan bahwa upaya penanggulangan kejahatan lewat jalur penal lebih menitikberatkan pada sifat represif (penindasan/ pemberantasan/penumpasan) sesudah kejahatan terjadi, sedangkan jalur non penal lebih menitikberatkan pada sifat preventif (pencegahan/penangkalan/

\footnotetext{
${ }^{11}$ H. Salim HS, Erlies Septiana Nurbani, Op.Cit, halaman 26.

${ }^{12}$ Ishaq, Op.Cit, halaman 91.

${ }^{13}$ H. Salim HS, Erlies Septiana Nurbani, Op.Cit, halaman 19.

${ }^{14}$ Abdul Razak,Kabid Pencegahan Dan Pemberdayaan Masyarakat, Wawancara Tanggal 17 Februari 2017.

${ }^{15}$ Barda Nawawi Arief, Op.Cit, Halaman 45.
} 
pengendalian) sebelum kejahatan terjadi. Dikatakan sebagai perbedaan secara kasar karena tindakan represif pada hakekatnya juga dapat dilihat sebagai tindakan preventif dalam arti luas. ${ }^{16}$

Untuk itu, Badan Narkotika Nasional Provinsi Jambi lebih menekankan pada kebijakan nonpenal karena kebijakan penal merupakan bagian dari kebijakan nonpenal sebab tujuan akhir dari kebijakan penal adalah mencegah agar tidak terjadi lagi penyalahgunaan narkotika di Provinsi Jambi.

Kemudian kebijakan nonpenal yang dilakukan oleh Badan Narkotika Nasional Provinsi Jambi dalam menanggulangi tindak pidana narkotika yaitu melakukan penyuluhan di tingkat seklah-sekolah. Manurut Abdul Razak di dalam melakukan upaya nonpenal berupa penyuluhan, ada tim khusus untuk melakukan penyuluhan di tingkat SD, SMP, SMA dan Perguruan Tinggi Swasta maupunNegeriserta mengundang Tokoh Masyarakat, Tokoh Agama, Tokoh Pemuda. Badan Narkotika Nasional Provinsi Jambi sudah 28 kali dalam setahun melakukan penyuluhan. ${ }^{17}$

Alasan dilakukan penyuluhan di tingkat sekolah-sekolah karena anak-anak sekolah ini masih mudah untuk dipengaruhi pikirannya sehingga para pengedar dengan mudah untuk memanfaatkan anak-anak sekolah ini menjadi penyalahguna narkotika sebab apabila anak-anak sekolah itu telah menjadi penyalahguna narkotika, secara otomatis anak-anak tersebut akan menjadi pelanggan untuk membeli narkotika kepada si pengedar tersebut. Mengingat begitu besar bahaya yang mengancam anak-anak sekolah tersebut, untuk itu dilakukan penyuluhan di sekolah-sekolah untuk mencegah agar anak-anak sekolah tersebut tidak mudah terpengaruh bujuk rayu pihak lain yang mereka belum kenal sehingga si pengedar narkotika tersebut merasa kesulitan untuk melakukan aksinya.

Berkaitan dengan hal tersebut, Sujono dan Bony Danieljuga sependapat bahwa untuk meningkatkan pemahaman dan kesadaran masyarakat akan bahaya narkotika serta agar mereka mengerti akibat atau sanksi hukum yang berat terhadap penyalahgunaan, penyimpanan, pemakaian, penyalur dan pengedar gelap narkotika, maka aparat terkait terlebih dahulu harusdisosialisasikan UU Narkotika yang baru ini kesegenap lapisan masyarakat, sehingga dapat dicegah korban-korban sanksi yang mestinya tidak perlu terjadi. ${ }^{18}$

Dengan demikian, kebijakan nonpenal dengan menggunakan penyuluhan di sekolah-sekolah sangat penting di dalam menanggulangi kejahatan narkotika yang selama ini terus mengancam keselamatan generasi muda. Dengan diadakannya penyuluhan di sekolah-sekolah terhadap pelajar, diharapkan terhadap pelajar untuk dapat waspada bahkan bila perlu menjauhi narkotika tersebut karena bahaya narkotika sangat mengancam generasi muda. Selain itu, apabila ada pelajar yang telah menjadi korban dari penyalahguna narkotika diharapkan juga untuk segera melapor kepada Badan Narkotika Nasional Provinsi Jambi/Badan Narkotika Nasional Kota Jambiguna untuk mendapatkan pengobatan sebelum menjadi pecandu berat narkotika.

Mengingat penyalahguna narkotika yang sekarang ini semakin di Provinsi Jambi, maka kebijakan nonpenal yang dilakukan oleh Badan Narkotika Nasional Provinsi Jambi selain penyuluhan yang di sekolahsekolah terhadap anak-anak pelajar, Badan Narkotika Nasional Provinsi Jambi juga melakukan rehabilitasimedis terhadap penyalahguna narkotika yang telah terlanjur menggunakan narkotika untuk supaya penyalahguna narkotika itu terlepas dari ketergantungan akan narkotika.

Rehabilitasi medis terhadap penyalahguna narkotika dilakukan oleh Badan Narkotika Nasional Provinsi Jambidi rumah sakit yang ditunjuk oleh Menteri. Terkait dengan rehabilitasi medis, Badan Narkotika Nasional Provinsi Jambimelakukannya di Rumah Sakit Jiwa Jambi. Dalam melakukan rehabilitasi medis tersebut, Rumah Sakit Jiwa Jambi hanya mampu menampung penyalahguna narkotika sebanyak 10 orang saja dan apabila penyalahguna narkotika tersebut banyak, maka Badan Narkotika Nasional Provinsi Jambi memerintahkan para penyalahguna narkotika tersebut untuk di rehabilitasi di Bogor saja. ${ }^{19}$

Selain Badan Narkotika Nasional Provinsi Jambi melakukan rehabilitasi medis terhadap penyalahguna narkotika,Badan Narkotika Nasional Provinsi Jambi juga melakukan rehabilitasi sosial terhadap mantan

${ }^{16}$ Abintoro Prakoso, Op.Cit, halaman 159.

${ }^{17}$ Abdul Razak, Kabid Pencegahan Dan Pemberdayaan Masyarakat, Wawancara Tanggal 17 Februari 2017.

18 AR. Sujono, Bony Daniel, Komentar dan Pembahasan Undang-Undang Nomor 35 Tahun 2009 Tentang Narkotika (Jakarta: Sinar Grafik, 2011), halaman 14.

19 Toha Suharto, Kepala Badan Narkotika Nasional Provinsi Jambi, Wawancara Tanggal 17 Februari 2017. 
penyalahguna narkotika tersebut. Rehabilitasi sosial tersebut diselenggarakan oleh instansi pemerintah maupun masyarakat melalui pendekatan keagamaan dan tradisional.

Adapun tempat rehabilitasi sosial yang dilakukan Badan Narkotika Nasional Provinsi Jambi yaitu di tiga Pondok Pesantren yang meliputi Pondok Pesantren Kalimo Sodo di KabupatenMerangin,Pondok Pesantren Al Khairat diKabupaten Tanjung Jabung Barat dan Pondok Pesantren Al Faqih di Kasang Pudak, Kota Jambi. ${ }^{20}$

Hal yang senada juga pernah dikemukakan oleh sudarto bahwa kegiatan KarangTaruna, kegiatan Pramuka danpenggarapan kesehatan jiwa masyarakat dengan pendidikan agama merupakan upaya-upaya nonpenal dalam mencegah dan menganggulangi kejahatan. ${ }^{21}$

Dengan demikian, kebijakan nonpenal oleh Badan Narkotika Nasional Provinsi Jambi terhadap penyalahguna narkotikaberupa melakukan rehabilitasi medis yang dilakukan di Rumah Sakit Jiwa Jambi dan rehabilitasi sosial yang dilakukan dengan pendekatan keagamaan yang ditempatkan di Pondok Pesantren di Jambi.

\section{Kendala-Kendala Yang Dihadapi Dalam Melakukan Kebijakan Nonpenal Oleh Badan Narkotika Nasional Provinsi Jambi Terhadap Penyalahguna Narkotika}

Ketika melakukan suatu kebijakan tentu ada kendala-kendala yang akan dihadapi di dalam melakukan penerapan kebijakan tersebut. Adapun kendala-kendala yang dihadapi oleh Badan Narkotika Nasional Provinsi Jambidilapangan dalammelakukan kebijakan nonpenal adalah terletak pada diri penyalahguna narkotika itu sendiri dan keluarga penyalahguna narkotika.

Sulitnya Badan Narkotika Nasional Provinsi Jambi dalam melakukan kebijakan nonpenal berupa rehabilitasi terhadap penyalahguna narkotika karena penyalahguna narkotika itu sendiri tidak mau melaporkan dirinya ke Badan Narkotika Nasional Provinsi Jambi.Penyalahguna narkotika tersebut tidak mau melaporkan dirinya ke Badan Narkotika Nasional Provinsi Jambi dengan alasan bahwa dia takut apabila nanti melaporkan ke Badan Narkotika Nasional Provinsi Jambi, dirinya akan dikenakan pidana penjara bukan di rehabilitasi.Hal yang demikian ini dapat terjadi karena kurangnya pemahaman penyalahguna narkotika akan adanya rehabilitasi.

Tidak hanya itu saja, keluarga penyalahguna narkotika juga tidak mau melaporkan anaknya sebagai penyalahguna narkotika ke Badan Narkotika Nasional Provinsi Jambi dengan alasan apabila nanti orang tua atau keluarganya melaporkan anaknya ke Badan Narkotika Nasional Provinsi Jambi, dikhawatirkan dari orang tuanya itu adalah anaknya tidak mendapatkan rehabilitasi dan akan dimasukkan ke penjara.

Kemudian kurangnya partisipasi masyarakat terhadap tetangga atau teman dekatnya yang menjadi pecandu narkotika. Hal yang demikian dilakukan oleh masyarakat tersebut dengan alasan tidak mau ikut campur urusan tetangga ataupun urusan teman dekat. Hal yang demikian sudah terlihat bahwa adanya sifat masa bodoh atau acuh dari masyarakat terhadap lingkungan sekitarnya.

Dengan sifat acuh dan tidak perduli yang dilakukan oleh masyarakat akan memudarkan tujuan dari penegakan hukum itu sendiri karena menurut Soerjono Soekanto, penegakan hukum berasal dari masyarakat dan bertujuan untuk mencapai kedamaian di dalam masyarakat. Oleh karena itu, dipandang dari sudut tertentu, maka masyarakat dapat mempengaruhi penegakan hukum tersebut. ${ }^{22}$ Dengan demikian, apabila masyarakat tersebut peduli dengan tetangga dan teman dekatnya tanpa disadari bahwa masyarakat tersebut telah mencapai tujuan untuk menciptakan kedamaian di tempat tinggalnya karena apabila tidak ada lagi penyalahguna narkotika di tempat tersebut maka tempat tersebut aman dan sebaliknya apabila terdapat penyalahguna di tempat tinggal masyarakat tersebut, maka akan menimbulkan kejahatan baru seperti apabila penyalahguna narkotika itu tidak ada uang untuk membeli narkotika, timbul niat dari penyalahguna narkotika itu untuk mencuri dengan tujuan untuk dapat membeli narkotika karena penyalahguna narkotika itu telah ketergantungan akan narkotika tersebut.

\footnotetext{
${ }^{20}$ Abdul Razak, Kabid Pencegahan Dan Pemberdayaan Masyarakat, Wawancara Tanggal 17 Februari 2017.

${ }^{21}$ Barda Nawawi Arief,Op.Cit, halaman 45.

${ }^{22}$ Soerjono Soekanto, faktor-Faktor Yang Mempengaruhi Penegakan Hukum (Jakarta:PT. Raja Grafindo Persada, 2012), halaman 45 .
} 
Dengan demikian, pencegahan kejahatan (upaya nonpenal) memfokuskan diri pada campur tangan sosial, ekonomi dan berbagai area kebijakan publik dengan maksud mencegah terjadinya kejahatan.Bentuk lain dari ketertiban masyarakat, dampak dari upaya pencegahan kejahatan yang terfokus pada akar kejahatan atau pencegahan situasional dan peningkatan kapasitas masyarakat dalam penggunaan sarana kontrol sosial informal. Perkembangan terakhir rela pada peningkatan keseimbangan pencegahan kejahatan yang berorientasi pada pelaku dan berorientasi pada korban. ${ }^{23}$

Kebijakan atau upaya penanggulangan kejahatan pada hakikatnya merupakan bagian integral dari upaya perlindungan masyarakat (social defence) dan upaya mencapai kesejahteraan masyarakat (social welfare).Oleh karena itu, dapat dikatakan bahwa tujuan akhir kebijakan adalah perlindungan masyarakat untuk mencapai kesejahteraan masyarakat. ${ }^{24}$

Selain itu, kendala-kendala yang masih ada di lapangan yaitu belum ada tempat rehabilitasi di kantor Badan Narkotika Nasional Provinsi Jambi. Di Jambi tempat rehabilitasi yang dilakukan oleh Badan Narkotika Nasional Provinsi Jambi yaitu Rumah Sakit Jiwa Jambi, itupun hanya mampu menampung 10 orang pecandu narkotika. Sedangkan untuk pecandu kelas berat akan dikirim ke Balai Besar rehabilitasi narkoba di Indonesia. ${ }^{25}$ Balai Besar Rehabilitasi yang dikelola oleh BNN berada di empat lokasiyaituLido (Bogor), Baddoka (Makasar), Tanah Merah (Kalimantan) dan Kepulauan Riau (Batam). ${ }^{26}$ Semua korban narkoba diarahkan ke rehabilitasi yang ada di empat lokasi tersebut. Kota Jambi sendiri belum memiliki panti rehabilitasi yang bisa dimanfaatkan untuk pengguna narkoba di Jambi.

Hal yang demikian sudah seharusnya diperhatikan oleh pemerintah karena mengingat Jambi telah banyak yang menjadi penyalahguna narkotika. Apabila tempat rehabilitasi hanya menampung 10 orang saja dan di kantor Badan Narkotika Nasional Provinsi Jambi belum ada tempat rehabilitasi, dikhawatirkan para pecandu akan terus ketergantungan pada narkotika sehingga nantinya sulit untuk menyembuhkan pecandu karena telah menjadi pecandu berat narkotika.

Jadi, Selain kendala-kendala dari diri dan keluarga pecandu serta kurangnya partisipasi masyarakat, kendala-kendala lain seperti belum ada tempat panti rehabilitasi di kantor Badan Narkotika Nasional Provinsi Jambijuga menjadi dominan dalam mengatasi penyalahgunaan narkotika sehingga program rehabilitasi belum optimal dalam pelaksanaannya.

\section{Solusi Yang Dilakukan Dalam Melaksanakan Kebijakan Non Penal Badan Narkotika Nasional Provinsi Jambi Terhadap Tindak Pidana Narkotika}

Mengingat banyaknya kendala-kendala yang masih menjadi perhatian khususnya untuk Badan Narkotika Nasional Provinsi Jambi, makasolusi yang seharusnya dilakukan oleh Badan Narkotika Nasional Provinsi Jambi dalam melakukan kebijakan nonpenal adalah Badan Narkotika Nasional Provinsi Jambiharus melakukan sosialisasi tidak hanya di sekolah-sekolah saja, akan tetapi Badan Narkotika Nasional Provinsi Jambi juga melakukan sosialisasi tentang bahaya narkotika dan memberikan wawasan tentang pentingnya rehabilitasi kepada pecandu, keluarga pecandu dan masyarakat agar mereka mau melaporkan keluarga atau tetangga yang telah menjadi pecandu narkotika.

Tidak hanya itu saja, Badan Narkotika Nasional Provinsi Jambi juga harus mengadakan komunitaskomunitas dari para mantan penyalahguna narkotika yang sudah sembuh guna untuk dijadikan pembimbing untuk penyalahguna narkotika yang baru masuk rehabilitasi. Dengan adanya komunitas-komunitas seperti ini, penyalahguna narkotika yang baru masuk akan terbuka wawasannya dan mau menjalani rehabilitasi dan ketika keluar dari rehabilitasi penyalahguna narkotika tersebut bisa mempengaruhi para orang lain agar tidak memakai narkotika.

Salah satu aspek kebijakan sosial yang kiranya patut mendapat perhatian ialah penggarapan masalah kesehatan jiwa masyarakat, baik secara individual sebagai anggota masyarakat maupun kesehatan/kesejahteraan keluarga (termasuk masalah kesejahteraan anak dan remaja) serta masyarakat luas pada umumnya. ${ }^{27}$

\footnotetext{
${ }^{23}$ Ibid, halaman 160.

${ }^{24}$ Barda Nawawi Arief, Op.Cit, halaman 4.

25 Toha Suharto, Kepala Badan Narkotika Nasional Provinsi Jambi, Wawancara Tanggal 17 Februari 2017.

${ }^{26}$ Ratna, Aspek Pidana : Penyalahgunaan Narkotika (Yogyakarta: legality, 2017), halaman 117.

${ }^{27}$ Barda Nawawi Arief, Op.Cit, halaman 45.
} 
Untuk itu, dengan dilakukan sosialisasi terhadap terhadap penyalahguna narkotika dan keluarga penyalahguna narkotika maka secara langsung telah menggarap masalah kesehatan jiwa khususnya terhadap diri penyalahguna narkotika dan secara umum menumbuhkan ketenangan di dalam masyarakat karena jika tidak ada lagi penyalahguna narkotika di tempat tersebut maka tingkat kejahatan seperti pencurian menjadi tidak ada lagi dan anak-anak remaja juga aman dari ancaman kejahatan narkotika yang dapat mengancam diri para remaja tersebut.

Disamping upaya-upaya nonpenal dapat ditempuh dengan menyehatkan masyarakat lewat kebijakan sosial dan dengan menggali berbagai potensi yang ada di dalam masyarakat itu sendiri, dapat pula upaya nonpenal itu digali dari berbagai sumber lain yang juga mempunyai potensi efek preventif seperti media pers/media massa, pemanfaatan kemajuan teknologi dan pemanfaatan potensi efek preventif dari aparat penegak hukum. ${ }^{28}$

Media massa harus keberpihakan yang jelas kepada korban, mereka tidak boleh melakukanpolitisasi pemberitaan yang mengakibatkan pengusutan suatu perkaramenjadi kabur. Pernyataan ini perlu ditegaskan mengingat sebagian besar media massa saat ini dikuasai oleh kelompok tertentu yang tidak jarang memiliki aktivitas yang berpotensi terjadinya pelanggaran hukum. ${ }^{29}$

Oleh karena itu, Badan Narkotika Nasional Provinsi Jambi harus bekerja sama dengan pihak media massa dalam memberikan berita tentang bahaya akan menyalahgunaan narkotika dapat memberikan wawasan terhadap yang menonton acara tersebut dan tanpa disadari dengan memberikan tayangan-tayangan tersebut akan membuat para penonton untuk tidak menggunakan narkotika karena mereka telah mengetahui akibat jika menggunakan narkotika dari tayangan tersebut.

Selain upaya nonpenal yang dapat dilakukan di atas, Sudarto pernah mengemukakan bahwa kegiatan patroli dari polisi yang dilakukan secara kontinu termasuk upaya nonpenal yang mempunyai pengaruh preventif bagi penjahat (pelanggar hukum) potensial. ${ }^{30}$ Dengan adanya kegiatan razia atau operasi yang dilakukan kepolisian secara rutin di beberapa tempat tentu akan membuat para bandar dan pengedar merasa takut untuk melakukan peredaran narkotika karena apabila mereka nekat melakukan peredaran narkotika kepada pengguna narkotika, mereka pasti ditangkap oleh polisi yang sedang patroli. Dengan kegiatan patroli ini dapat memperkecil tingkat kejahatan yang dilakukan oleh para pengedar narkotika.

Kemudian Badan Narkotika Nasional Provinsi Jambi juga harus menyediakan panti rehabilitasi terhadap penyalahguna narkotika sehingga untuk penyalahguna narkotika yang berat tidak lagi dikirim ke Balai Besar Rehabilitasi yang dikelola oleh Badan Narkotika Nasional yang berada di empat lokasiyaituLido (Bogor), Baddoka (Makasar), Tanah Merah (Kalimantan) dan Kepulauan Riau (Batam) karena mengingat tempat rehabilitasi yang cukup jauh apabila penyalahguna narkotika tersebut berasal dari Provinsi Jambi.

\section{SIMPULAN}

Berdasarkan uraian yang telah dijelaskan dalam pembahasan, maka penulis dapat mengambil kesimpulan sebagai berikut :

1. Kebijakan nonpenal oleh Badan Narkotika Nasional Provinsi Jambi terhadap penyalahguna narkotika adalah Badan Narkotika Nasional Provinsi Jambi telah melakukan penyuluhan di sekolah-sekolah, melakukan rehabilitasi medis yang dilakukan di Rumah Sakit Jiwa Jambi dan rehabilitasi sosial yang dilakukan dengan pendekatan keagamaan yang ditempatkan di Pondok Pesantren di Jambi.

2. Kendala-kendala yang dihadapi dalam melakukan kebijakan nonpenal oleh Badan Narkotika Nasional Provinsi Jambi terhadap penyalahguna narkotika adalah pecandu dan keluarga pecandu tidak mau melapor, kurangnya peran serta masyarakat dan tidak ada tempat rehabilitasi di Badan Narkotika Nasional Provinsi Jambi.

3. Solusi dalam melakukan kebijakan nonpenal oleh Badan Narkotika Nasional Provinsi Jambi terhadap penyalahguna narkotika adalah Badan Narkotika Nasional Provinsi Jambi harus rutin melakukan sosialisasi kepada masyarakat, Badan Narkotika Nasional Provinsi Jambi dapat mengadakan komunitas-

\footnotetext{
${ }^{28}$ Fathul Achmadi Abby, Pengadilan Jalanan Dalam Dimensi Kebijakan Kriminal Jalan (Jakarta: Permata Aksara, 2016), halaman 119.

${ }^{29}$ M. Ali Zaidan, Kebijakan Kriminal (Jakarta: Sinar Grafika, 2016), halaman 113.

${ }^{30}$ Abintoro Prakoso, Op.Cit, halaman 160.
} 
komunitas dari para mantan penyalahguna narkotika yang sudah sembuh untuk dijadikan pembimbing terhadap penyalahguna narkotika yang baru masuk rehabilitasi, Badan Narkotika Nasional Provinsi Jambi harus bekerja sama dengan kepolisian untuk melakukan razia, Badan Narkotika Nasional Provinsi Jambi dapat menggunakan peran media massa dalam memberikan berita tentang bahaya menyalahgunaan narkotikadan Badan Narkotika Nasional Provinsi Jambi harus menyediakan panti rehabilitasi penyalahguna narkotika.

\section{DAFTAR PUSTAKA}

\section{Buku}

Abintoro Prakoso, Kriminologi Hukum Pidana, Yogyakarta: Laksbang Grafika, 2013

AR. Sujono, Bony Daniel, Komentar dan Pembahasan Undang-Undang Nomor 35 Tahun 2009 Tentang Narkotika, Jakarta: Sinar Grafik, 2011

Barda Nawawi Arief, Bunga Rampai Kebijakan Hukum Pidana Perkembangan Penyusunan Konsep KUHP Baru, Jakarta: Kencana, 2014

Fathul Achmadi Abby, Pengadilan Jalanan Dalam Dimensi Kebijakan Kriminal Jalan, Jakarta: Permata Aksara, 2016

H. Salim HS, Erlies Septiana Nurbani, Penerapan Teori Hukum Pada Penelitian Tesis dan Disertasi, Jakarta: PT. Raja Grafindo Persada, 2013

I Made Pasek Diantha, Metodologi Penelitian Hukum Normatif Dalam Justifikasi Teori Hukum, Jakarta, Kencana, 2016

Ishaq, Metode Penelitian Hukum Dan Penulisan Skripsi, Tesis Serta Disertasi, Bandung: Alfabeta, 2017

Ratna, Aspek Pidana : Penyalahgunaan Narkotika, Yogyakarta: legality, 2017

Salim HS dan Erlies Septiana Nurbani, Penerapan Teori Hukum Pada Penelitian Tesis Dan Disertasi, Jakarta, PT. Raja Grafindo Persada, 2013

Siswanto S, Politik Hukum Dalam Undang-Undang Narkotika, Jakarta: PT Renika Cipta, 2012

Soerjono Soekanto, faktor-Faktor Yang Mempengaruhi Penegakan Hukum, Jakarta: PT. Raja Grafindo Persada, 2012

\section{Peraturan Perundang-undangan}

Undang-Undang Nomor 35 Tahun 2009 Tentang Narkotika 